\title{
Operational Robustness Studies of Solid Oxide
}

\section{Electrolysis Stacks}

\author{
Karen Wonsyld ${ }^{1}$, Lone Bech ${ }^{2}$, Jens Ulrik Nielsen ${ }^{1}$ and Claus Friis Pedersen ${ }^{2}$ \\ 1. Research and Development, Topsoe Fuel Cell A/S, Kgs. Lyngby, 2800, Denmark \\ 2. Research and Development, Haldor Topsoe A/S, Kgs. Lyngby, 2800, Denmark
}

Received: August 11, 2014 / Accepted: September 30, 2014 / Published: February 28, 2015.

\begin{abstract}
Stacks of solid oxide cells which can be run as both electrolysers and fuel cells have been tested for robustness towards simulations of stress conditions which are likely to occur during operation of solid oxide electrolysis systems, for which the energy supply comes from renewable sources, such as wind mills and solar cells. Such conditions are thermo mechanical stress conditions as well as loss of fuel and air supply. The cells have Ni/YSZ (yttria stabilized zirconia) fuel electrodes, YSZ electrolytes, and LSCF (lanthanum strontium cobalt ferrite) oxygen electrodes with a CGO (cerium gadolinium oxide) barrier layer. In the stacks, the cells are separated by chromium rich steel interconnects. The robustness tests of stacks are one step in the development of a SOEC (solid oxide electrolysis cell) core; the core component in a SOEC system, including one or more SOEC stacks, heaters, heat exchangers, insulation, and feed troughs.
\end{abstract}

Key words: Solid oxiede electrolysis, solid oxide fuel cell energy storage, degradation, robustness.

\section{Introduction}

If the greater part of the world's energy production is to be produced from renewable energy resources, it will be necessary to compensate for the fact that the energy production level does not follow the consumption level. Thus, energy from high production and low consumption periods will need to be stored to avoid major efficiency losses. The best long lasting storage method is to convert the excess energy into a fuel. Electrolysis has long been proposed as energy converter for excess electricity for nuclear power plants where the production is difficult to adjust frequently. Especially HTE (high temperature electrolysis) is attractive for this as it can utilize excess heat from the nuclear plants and other sources due to its higher efficiency compared with low temperature electrolysis [1]. As both the energy consumption and the production level from nuclear power plants are

Corresponding author: Karen Wonsyld, Ph.D., research scientist, research fields: battery materials (presently), SOFC and SOEC (previously). E-mail: kawo@topsoe.dk. foreseeable, changes in storage needs can be predicted in advance. Thus, HTE systems can be operated without sudden load changes and loss of electricity supply. This is not the case if HTE is to be used as energy converter for wind or solar energy. Especially, wind energy can show large and rapid fluctuations, which are quite unforeseeable. In Denmark, where there is a large potential for wind energy, the national energy strategy [2] made by Energinet suggests that electrolysis can be an attractive solution for energy conversion. The idea is to produce $\mathrm{H}_{2}$ or $\mathrm{CO}$; the latter through co-electrolysis to syngas using a mixture of $\mathrm{H}_{2} \mathrm{O}$ and $\mathrm{CO}_{2}$ as feedstock in the electrolyser [3]. Due to the wind fluctuations, it is necessary either that the electrolysis stacks can withstand rapid changes or that a sophisticated system compensates for the fluctuations such that temperature gradients and current fluctuations are minimised, which can make sure that no sudden failures occur, such as failure to provide fuel, cooling air, or electricity. Calculations regarding system operation for proper temperature distributions 
have been carried out by Cai et al. [4] and Udagawa et al. [5] who have found that the temperature can be evened out through air flow over the oxygen electrodes in both endothermic and exothermic operation, but also that for thermo neutral operation, this method is little efficient. A thermo neutral operation point is defined as where the heat consumed by the endothermic electrolysis reaction evens out with the heat generated from ohmic resistance to the current. Xie et al. [6] have described how to dampen the electrical fluctuations caused by the wind fluctuations for better operation.

\section{Scientific Approach}

It is desirable to obtain a simple and compact system in order to limit the system cost as well as thermal losses. Thus, although, a system can decrease the effect of the variations the cells will be subject to, it is an advantage to have a SOEC (solid oxide electrolysis cell) stack which requires as little from the system as possible. At Haldor Topsoe A/S a SOEC core, Fig. 1, including one or more SOEC stacks, heaters, heat exchangers, insulation, and feed troughs, is being developed. Such a SOEC core can easily be integrated in a SOEC system.

The stacks for the SOEC core have been developed at Topsoe Fuel Cell $\mathrm{A} / \mathrm{S}$ for robustness towards operation conditions which the SOEC core will be subject to in a SOEC system integrated with a renewable energy source.

The cells in the stacks are planar fuel electrode supported cells with porous Ni/YSZ fuel electrodes, YSZ electrolytes, and LSCF oxygen electrodes with a CGO barrier layer. The cells outer dimensions are 12 $\mathrm{cm} \times 12 \mathrm{~cm}$. Between the cells are interconnects of chromium rich steel. The stacks can be operated in either co-flow or counter-flow; that is the same direction fuel and air flows or opposed direction flows, respectively. The cells have been developed with emphasis on robustness as well as high conductivity in all layers. The latter is of importance not only for the beginning of life performance but also for the degradation of the cells. This is especially so for the oxygen electrode conductivity. Virkar [7] has found that delamination of the oxygen electrode caused by $\mathrm{O}_{2}$ accumulation is dependent on the conductivity of the oxygen electrode as the oxygen chemical potential increases with decreasing electronic conductivity. The oxygen electrodes have been developed to accommodate this. Oxygen electrode delamination has been found to be more difficult to prevent for SOEC than for SOFC operation due to accumulation of $\mathrm{O}_{2}$ at the electrolyte electrode interface. Also a number of other research groups have described this phenomenon, e.g., Sohal et al. [8], Laguna-Becero et al. [9], and Mawdsley et al. [10].

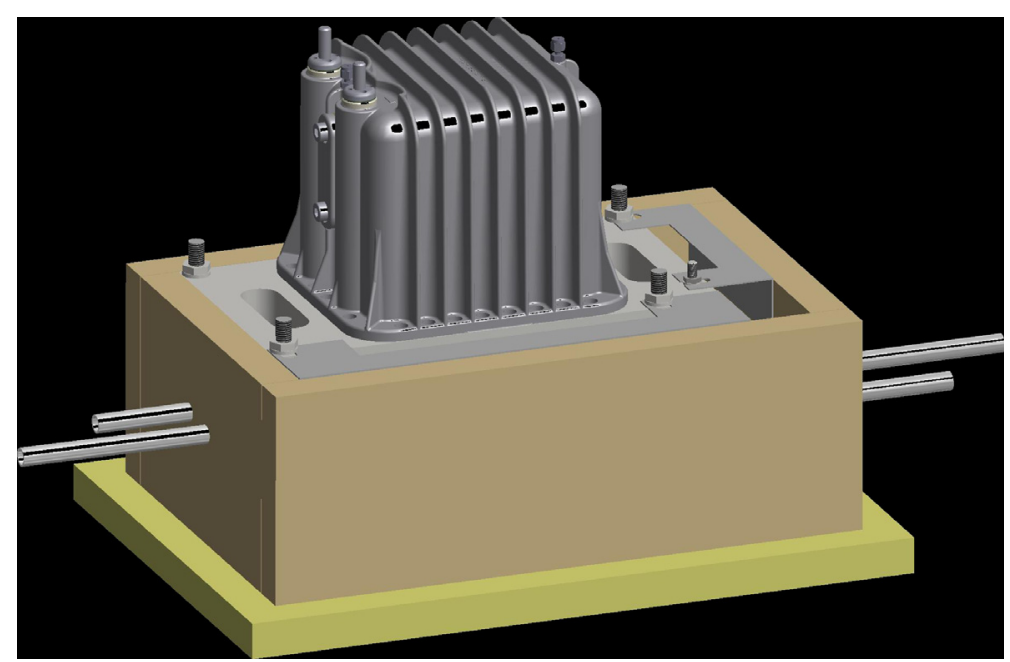

Fig. 1 Schematics of a SOEC core. The metal casing on the top of the box includes the stack as well as stack compression and air manifold. The SOEC core also includes heaters, heat exchangers, piping, and feed troughs. 
Stacks have been giving rise to different thermal gradient and alterations between these through tests. Also, effects of fuel and air supply loss have been investigated. Results from these tests are presented in the present study.

\section{Experiments}

\subsection{Cycles between Fuel Cell and Electrolysis Operation}

There are two major reasons for running cycles between SOFC (solid oxide fuel cell) and SOEC modes on stacks. One is to investigate the possibility of utilizing solid oxide stacks both as fuel cells and electrolysis cells in the same system; the operation mode depending on the production and consumption variations. The other reason is that the magnitude and distribution of temperatures are different for the two operation modes. This can cause volume changes and stress at the interfaces between cell layers and between the cells and interconnects. Effects from the potential cycles may also occur. SOFC-SOEC cycles tests are, thus, an effective method to detect weaknesses of the stacks for tolerating temperature and potential changes. The tests have been varied both regarding load and flow configuration as co and counter flow causes different temperature distributions.

\subsubsection{1/-656 $\mathrm{mA} \cdot \mathrm{cm}^{-2}$ Cycles Test}

A 10-cell stack was used for this test which was carried out in co-flow. The load in fuel cell mode was
$231 \mathrm{~mA} \cdot \mathrm{cm}^{-2}$ and in electrolysis mode $-656 \mathrm{~mA} \cdot \mathrm{cm}^{-2}$. The applied temperatures and flows were the same in electrolysis mode and fuel cell mode. Each mode was kept for $2 \mathrm{~h}$ at each cycle and the time for changing between cycles was approximately $10 \mathrm{~min}$. In total, 113 cycles were performed. Table 1 gives the flows and temperatures during the different test sequences. The SOFC operation point is a standard reference operation point for stack performance. The test stand used is a test stand build internally at Topsoe Fuel Cell A/S.

\subsubsection{0/-300 $\mathrm{mA} \cdot \mathrm{cm}^{-2}$ Cycles Test}

A 20-cell stack was tested in counter flow configuration. The loads in fuel cell and electrolysis mode were $+/-300 \mathrm{~mA} \cdot \mathrm{cm}^{-2}$ respectively. Such cycles were carried out at two different temperatures. These are given in Table 2 for cycles low $T$ and cycles high $T$ respectively. The corresponding flows are given in the same table. The applied temperatures and flows were the same in electrolysis mode and fuel cell mode. Each mode was kept for $2 \mathrm{~h}$ at each cycle and the time for changing between cycles was approximately $6 \mathrm{~min}$. In total, 148 cycles were performed at the low temperatures and 84 at the high temperatures.

\subsection{Operation without Air Flow to the Oxygen Electrode}

Some oxides undergo phase transitions at high temperatures and low oxygen partial pressures leading to chemical expansion. Perez-Coll et al. [11] have

Table 1 Flows and temperatures during the test. $\mathrm{H}_{2} \mathrm{O}, \mathrm{H}_{2}$, and $\mathrm{N}_{2}$ are supplied to the fuel side and air to the $\mathrm{O}_{2}$ side of the cells.

\begin{tabular}{lllllllll}
\hline & \multicolumn{2}{l}{$\begin{array}{l}\text { Current } \\
\left(\mathrm{mA} \cdot \mathrm{cm}^{-2}\right)\end{array}$} & \multicolumn{2}{l}{ Temperatures $\left({ }^{\circ} \mathrm{C}\right)$} & \multicolumn{5}{l}{$\begin{array}{l}\text { Flows }\left(\mathrm{Nl} \cdot \mathrm{h}^{-1} \text { or } \mathrm{g} \cdot \mathrm{h}^{-1} \text { for } \mathrm{H}_{2} \mathrm{O}\right) \\
\text { Air side flow }\end{array}$} \\
\hline Sequence & & Fuel in & Air in & Oven & $\mathrm{H}_{2} \mathrm{O}$ & $\mathrm{H}_{2}$ & $\mathrm{~N}_{2}$ & Air \\
\hline SOFC & $0-230$ & 532 & 641 & 711 & 0 & 150 & 100 & 1,080 \\
Cycles & $231 /-656$ & 532 & 675 & 718 & 336 & 278 & 0 & 1,250 \\
\hline
\end{tabular}

Table 2 Flows and temperatures during the test. $\mathrm{H}_{2} \mathrm{O}, \mathrm{H}_{2}, \mathrm{~N}_{2}$, and $5 \% \mathrm{H}_{2}$ in $\mathrm{He}$ are supplied to the fuel side and air to the $\mathrm{O}_{2}$ side.

\begin{tabular}{|c|c|c|c|c|c|c|c|c|}
\hline \multirow[b]{2}{*}{ Sequence } & \multirow[t]{2}{*}{ Current $\left(\mathrm{mA} \cdot \mathrm{cm}^{-2}\right)$} & \multicolumn{3}{|c|}{ Temperatures $\left({ }^{\circ} \mathrm{C}\right)$} & \multicolumn{4}{|c|}{$\begin{array}{l}\text { Flows }\left(\mathrm{Nl} \cdot \mathrm{h}^{-1} \text { or } \mathrm{g} \cdot \mathrm{h}^{-1} \text { for } \mathrm{H}_{2} \mathrm{O}\right) \\
\text { Air side flow }\end{array}$} \\
\hline & & Fuel in & Air in & Oven & $\mathrm{H}_{2} \mathrm{O}$ & $\mathrm{H}_{2}$ & $\mathrm{~N}_{2}$ & Air \\
\hline SOFC & $0-230$ & 480 & 675 & 750 & 0 & 300 & 200 & 1,920 \\
\hline Cycles low $T$ & $300 /-300$ & 576 & 688 & 750 & 295 & 733 & 0 & 5,934 \\
\hline Cycles high $T$ & $300 /-300$ & 576 & 704 & 800 & 295 & 733 & 0 & 4,460 \\
\hline
\end{tabular}


shown that CGO is subject to chemical expansion at very low oxygen partial pressures and between $800^{\circ} \mathrm{C}$ and $1,000{ }^{\circ} \mathrm{C}$ caused by reduction of $\mathrm{Ce}^{4+}$ into $\mathrm{Ce}^{3+}$. According to Lein et al. [12] and Towzelin [13], this is the case also for LSCF for which phase transition should partly occur below 9 mbar oxygen partial pressures at temperatures between $800{ }^{\circ} \mathrm{C}$ and $900{ }^{\circ} \mathrm{C}$ forming separate iron and cobalt oxides.

Very often one of the most unstable components of a system is the air blower. It is therefore of great importance that temporary loss of air supply does not damage the stack. Also, it will reduce system cost considerable if SOEC systems run entirely without an air flow to the oxygen side even at OCV (open circuit voltage) where no oxygen is transported to the oxygen electrode. In this experiment an 11-cell stack was operated in co-flow configuration with cycles between fuel cell $\left(231 \mathrm{~mA} \cdot \mathrm{cm}^{-2}\right)$ and electrolysis mode $(-656$ $\left.\mathrm{mA} \cdot \mathrm{cm}^{-2}\right)$ interrupted by periods with OCV and little or no air supply as well as stand by periods with a current of only $1 \mathrm{~A}$ but with operational flows. These conditions were repeated at different oven temperatures $\left(760^{\circ} \mathrm{C}\right.$, $810{ }^{\circ} \mathrm{C}$ and $835^{\circ} \mathrm{C}$, and the flow inlet temperatures were adjusted accordingly). The stress caused by the cycles should reveal if the bindings between layers have become weaker and the stand-by periods if a partial contact loss have been created by the SOEC-SOFC cycles. Partial contact losses are best seen at low currents, as this causes, cooling and slight material shrinkage compared with operational load conditions. After these robustness test variations, a degradation test in electrolysis mode at $-690 \mathrm{~mA} \cdot \mathrm{cm}^{-2}$ was carried out for $192 \mathrm{~h}$. This was in order to investigate if damage had occurred that would increase the degradation rate.

\subsection{Stack Behaviour at Fuel Shut-off}

Unexpected loss of fuel supply is likely to occur several times to most SOEC core during their lifetime. They should thus be able to withstand these incidents. Investigation of the stack response when the fuel flow is lost one step towards the development of durable

\section{SOEC core.}

Starvation was tested on a 10-cell stack when running in $\mathrm{CO}_{2}$ electrolysis mode at $-345 \mathrm{~mA} \cdot \mathrm{cm}^{-2}$ with $57 \%$ fuel utilization and $\mathrm{N}_{2}$ flows for flushing of the fuel and air side as summarized in Table 3. The stack bias required to obtain this load was $14.3 \mathrm{~V}$ and the upper limit was put $0.1 \mathrm{~V}$ higher. Starvation conditions were obtained by ramp down of the $\mathrm{CO}_{2}$ flow. After 2 min, there is nearly no $\mathrm{CO}_{2}$ flow left, leaving a $\mathrm{N}_{2}$ flow over both sides of the stack.

\section{Results}

\subsection{Cycles between SOFC and SOEC}

\subsubsection{1/-656 $\mathrm{mA} \cdot \mathrm{cm}^{-2}$ Cycles Test}

One hundred and thirteen cycles were carried out with asymmetric load. During those no degradation was observed as can be seen from Fig. 2. In electrolysis operation, the performance improved slightly over time, however, this probably reflects a slight temperature increase caused by increasing external temperatures, which affects the temperatures of the test system. The irregularity on February 16 was due to a load programming failure, which caused the load to get fixed at -42 A until the load ramping was re-started. The voltage fluctuations were caused by pulsation of the water evaporator. The average cell voltage was by the end of the test $1.32 \mathrm{~V}$ in electrolysis and $0.796 \mathrm{~V}$ in fuel cell operation. The average voltage over a shorter interval is shown in Fig. 3.

\subsubsection{0/-300 $\mathrm{mA} \cdot \mathrm{cm}^{-2}$ Cycles Test}

Figs. 5-7 display the overall voltage for all low temperature cycles, a zoom of a shorter time period on the voltage, and the outlet and stack temperatures, respectively. The corresponding graphs for the high temperature cycles are show in Figs. 8-10. The average voltage in electrolysis mode was $1.21 \mathrm{~V}$ by the end of the low temperature cycles test and $1.15 \mathrm{~V}$ during the high temperature cycles test. In fuel cell operation the corresponding numbers are $0.84 \mathrm{~V}$ and $0.85 \mathrm{~V}$. Thus, the temperature increase has as expected a larger effect 
Table 3 Flows, temperatures and current density for the starvation experiments during $\mathrm{CO}_{2}$ electrolysis. $\mathrm{CO}_{2}$ is supplied on the fuel side and both the air- and fuel-side are flushed with $\mathbf{N}_{2}$.

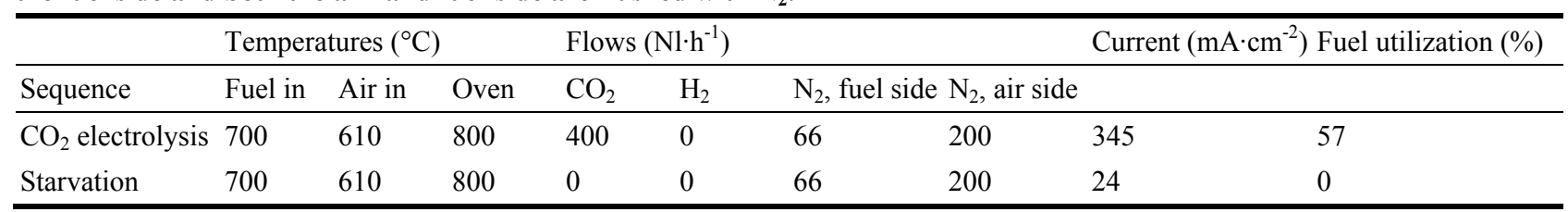

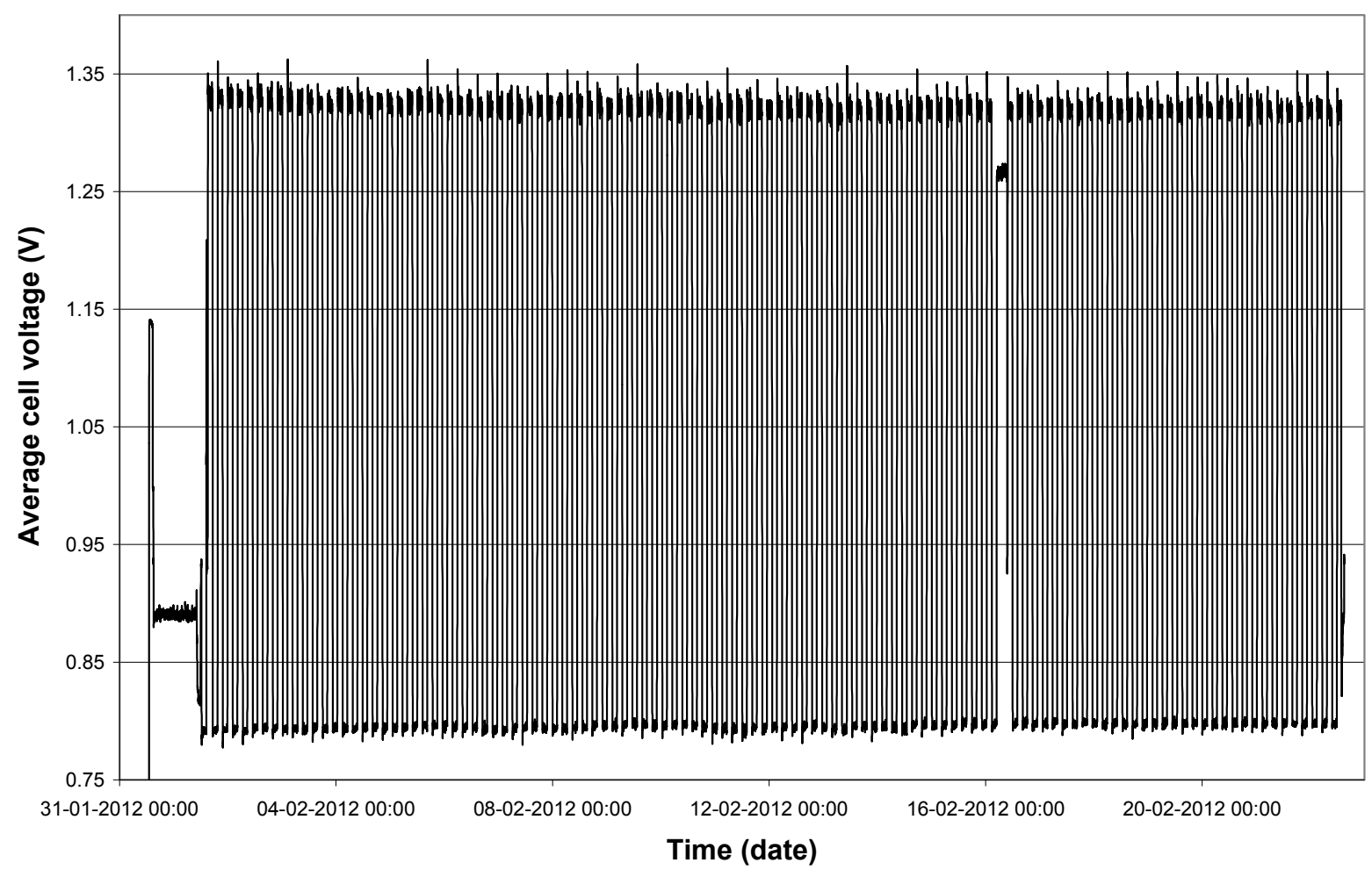

Fig. 2 Average cell voltage for cycles between $231 \mathrm{~mA} \cdot \mathrm{cm}^{-2}$ and $-656 \mathrm{~mA} \cdot \mathrm{cm}^{-2}$. The irregularity on the $16-02-2012$ is caused by a load supply problem.

on the electrolysis performance than on the fuel cell mode performance which corresponds with the electrolysis mode being endothermic at this load and that the Ni-YSZ electrodes have higher activity for $\mathrm{H}_{2}$ oxidation than for steam electrolysis as reported by Eguchi et al. [14], Marina et al. [15], and Kim-Lohsoontorn and Bae [16]. For the low temperature cycles, a degradation of 1.44 $\mathrm{m} \Omega \cdot \mathrm{cm}^{2} \cdot$ cycles $^{-1}$ was observed in electrolysis mode and $0.10 \mathrm{~m} \Omega \cdot \mathrm{cm}^{2} \cdot$ cycles $^{-1}$ in fuel cell mode. During the high temperature cycling, no degradation within normal variation was observed in either SOEC or SOFC mode. The asymmetric load test and the high temperature symmetric load test indicate that there is a temperature window between $760^{\circ} \mathrm{C}$ and $790{ }^{\circ} \mathrm{C}$ with a low degradation rate. Also it is reasonable to conclude from Figs. 4, 7, and 10, that the asymmetrical load case caused less thermo mechanical stress. Due to the low ohmic resistance of the electrolyte, the thermos neutral point in electrolysis mode is reached at about 919 $\mathrm{mA} * \mathrm{~cm}^{-2}$.

\subsection{Operation without Airflow over Oxygen Electrodes}

In Fig. 11, an overview of the most important parameters during the test sequence is given, while Figs. 12 and 13 display the average cell voltage during the test of air supply loss effect and of the subsequent degradation test in electrolysis mode, respectively. None of the sequences including OCV and no air followed by SOFC-SOEC cycles and then 1 


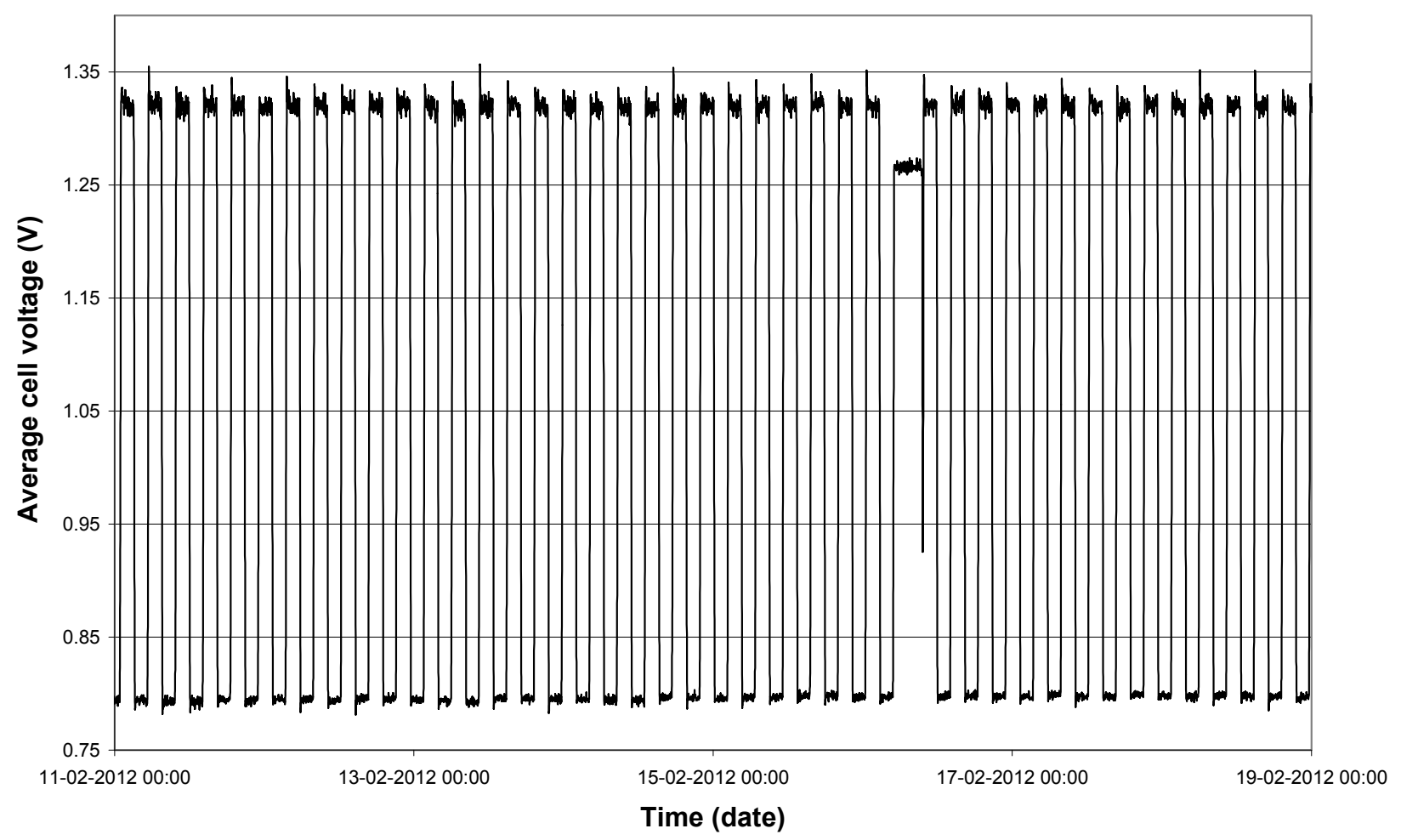

Fig. 3 Zoom on a smaller part of Fig. 2.

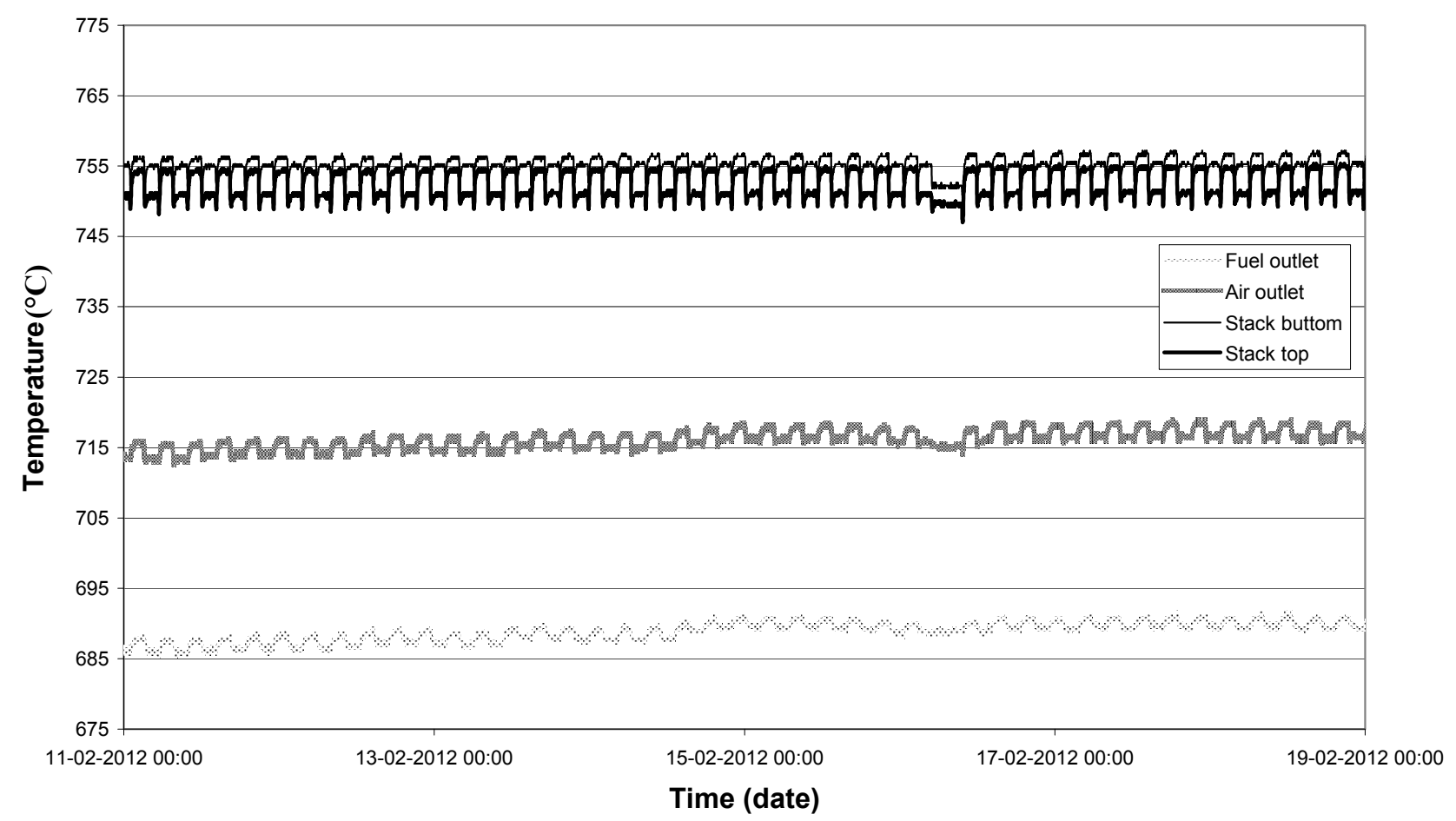

Fig. 4 Temperature variation during cycles between $231 \mathrm{~mA} \cdot \mathrm{cm}^{-2}$ and $-656 \mathrm{~mA} \cdot \mathrm{cm}^{-2}$. The high temperature intervals represent electrolysis operation. 


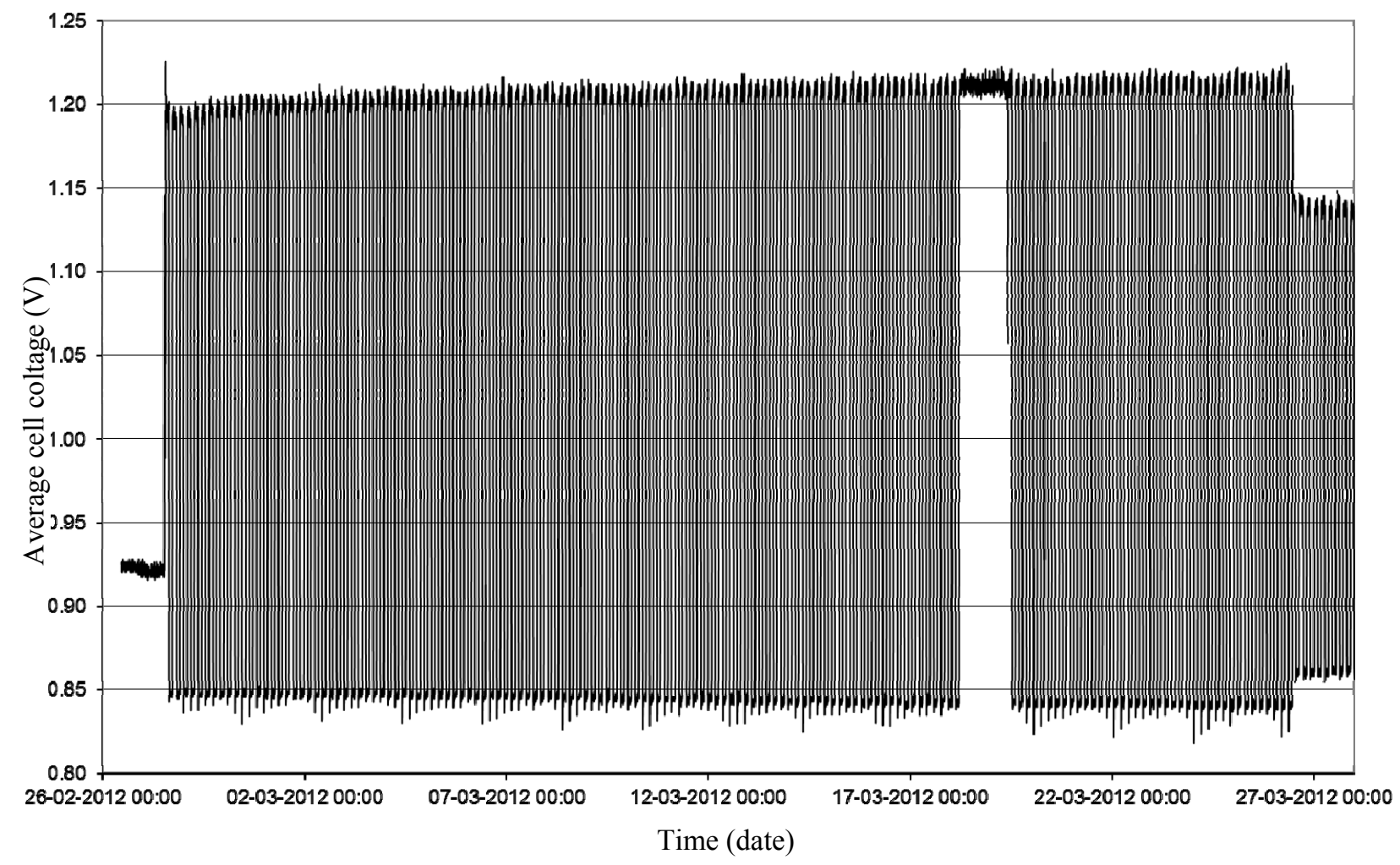

Fig. 5 Average cell voltage for cycles between $300 \mathrm{~mA} \cdot \mathrm{cm}^{-2}$ and $-300 \mathrm{~mA} \cdot \mathrm{cm}^{-2}$ at low temperature operation.

The irregularity on the 19-02-2012 is caused by a load supply problem.

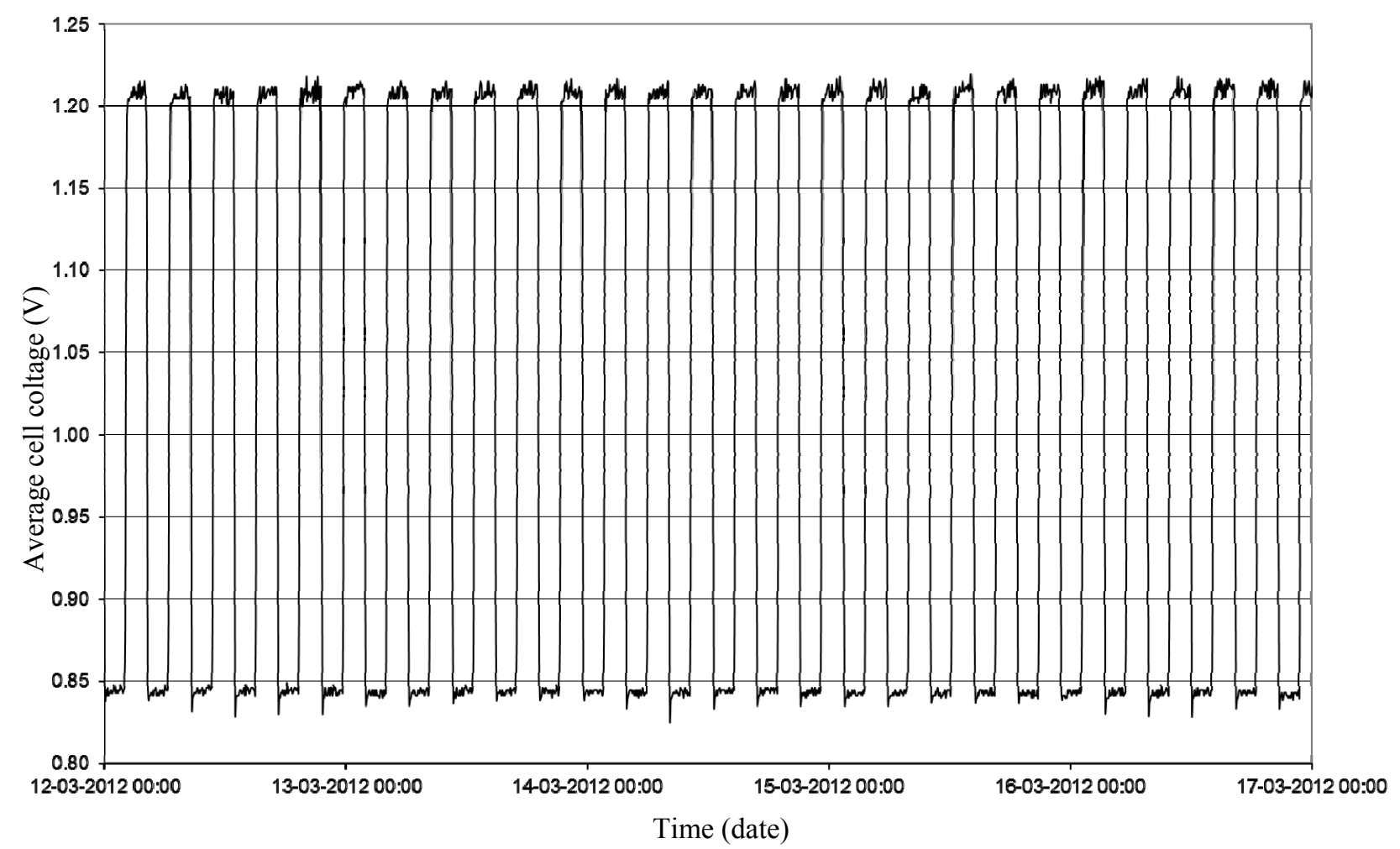

Fig. 6 Zoom on a smaller part of Fig. 5. 


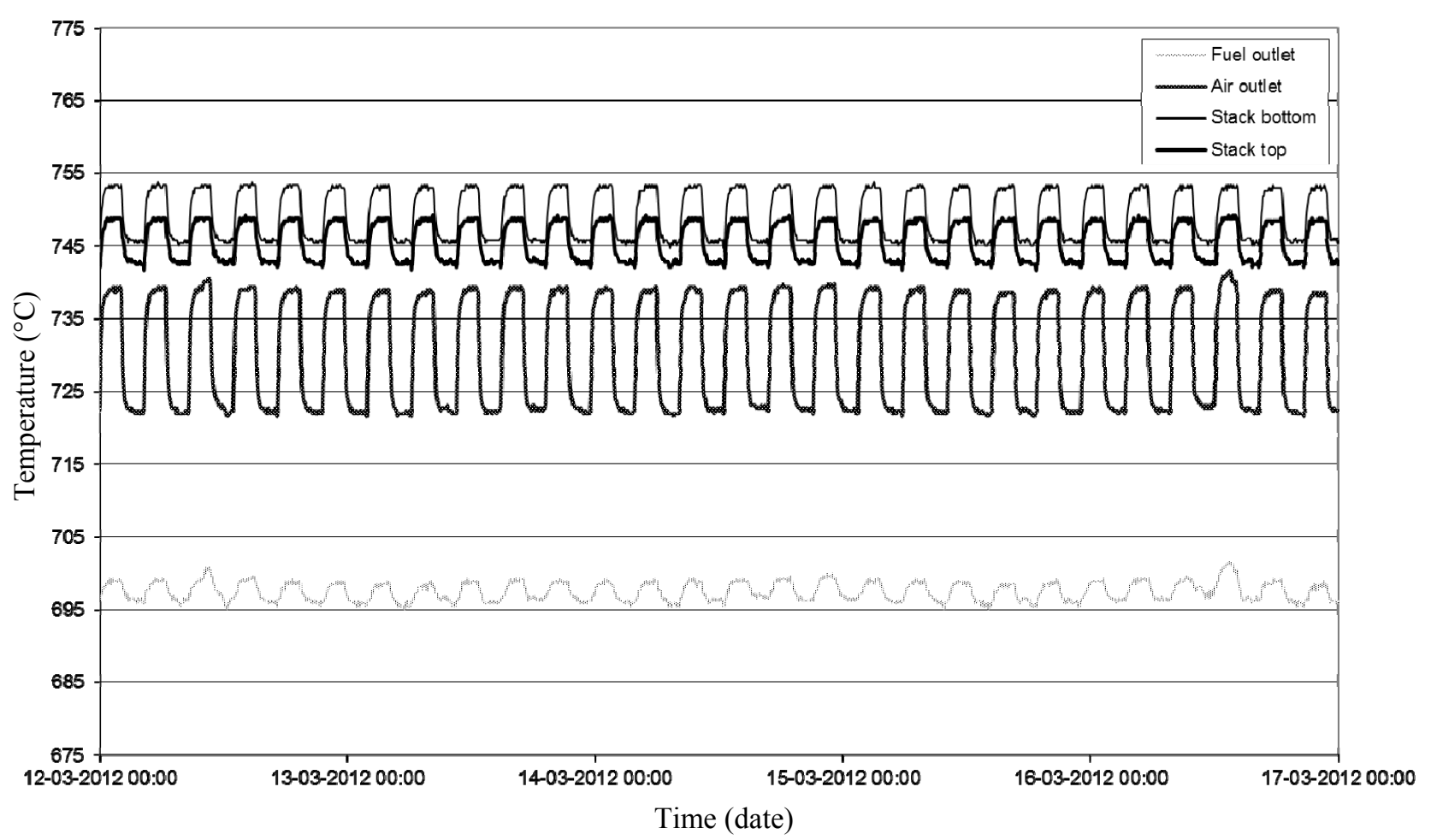

Fig. 7 Temperature variation during cycles between $300 \mathrm{~mA} \cdot \mathrm{cm}^{-2}$ and $-300 \mathrm{~mA} \cdot \mathrm{cm}^{-2}$ at Low temperature operation. The low temperature intervals represent electrolysis operation.

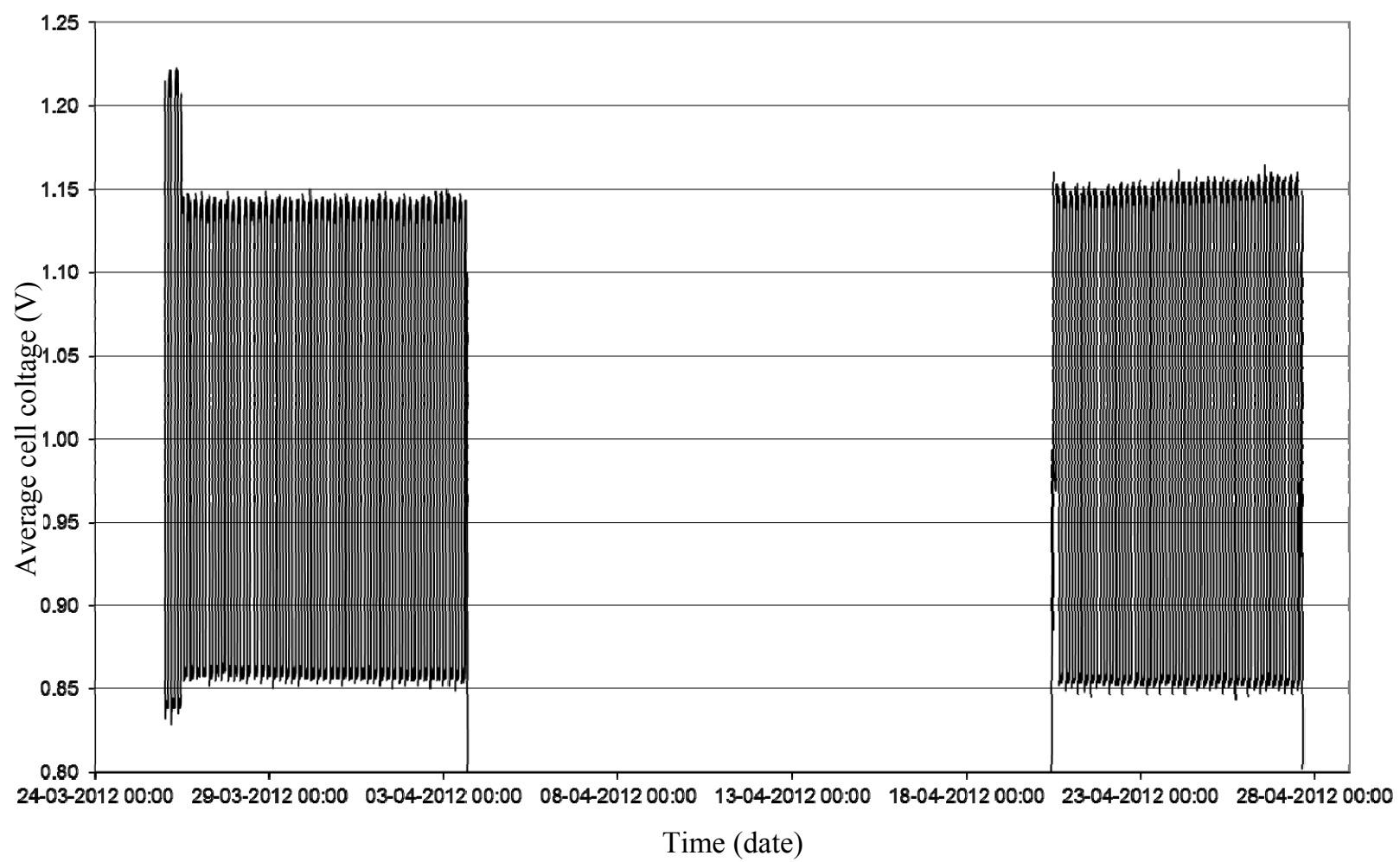

Fig. 8 Average cell voltage for cycles between $300 \mathrm{~mA} \cdot \mathrm{cm}^{-2}$ and $-300 \mathrm{~mA} \cdot \mathrm{cm}^{-2}$ at high temperature operation. 


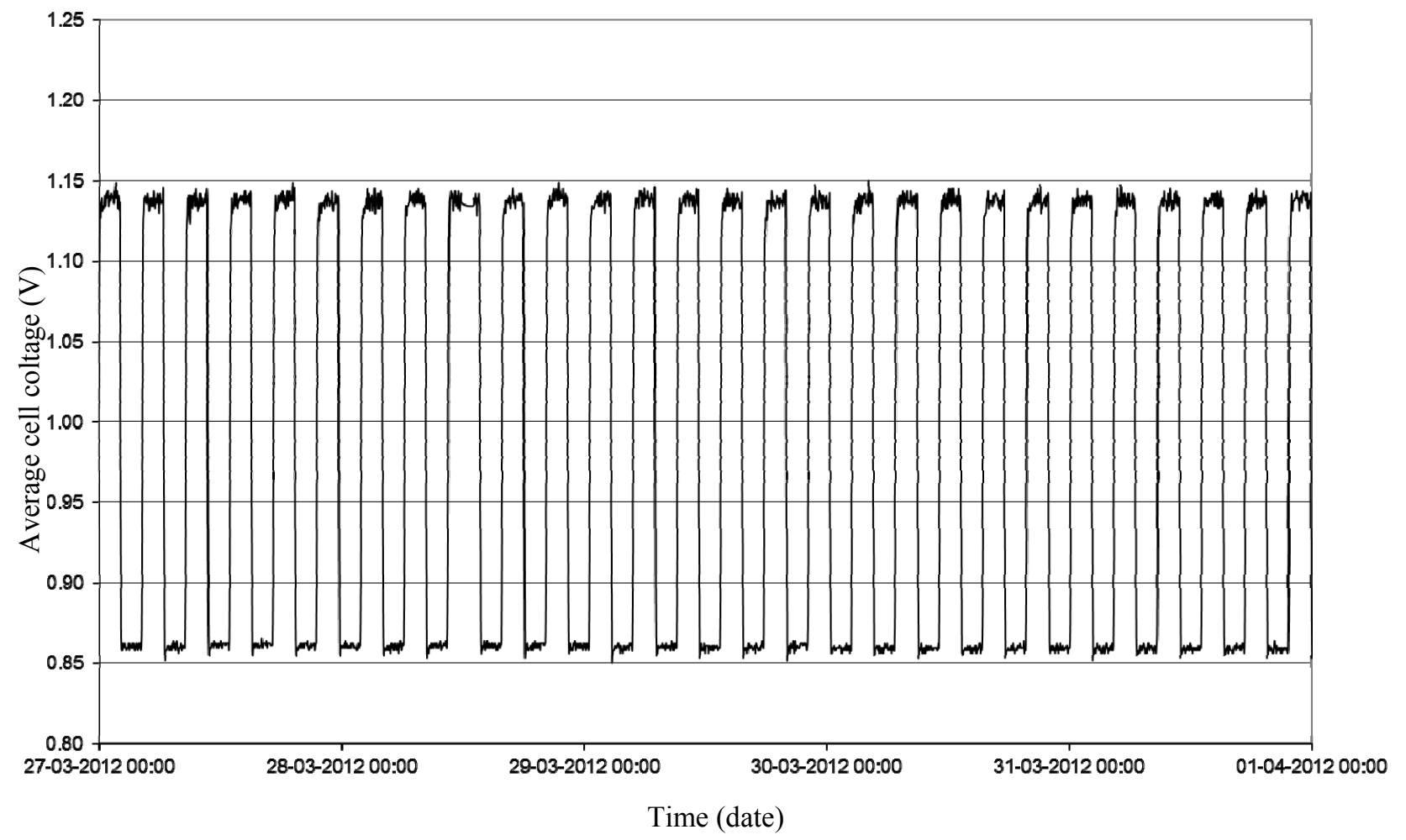

Fig. 9 Zoom on a smaller part of Fig. 8.

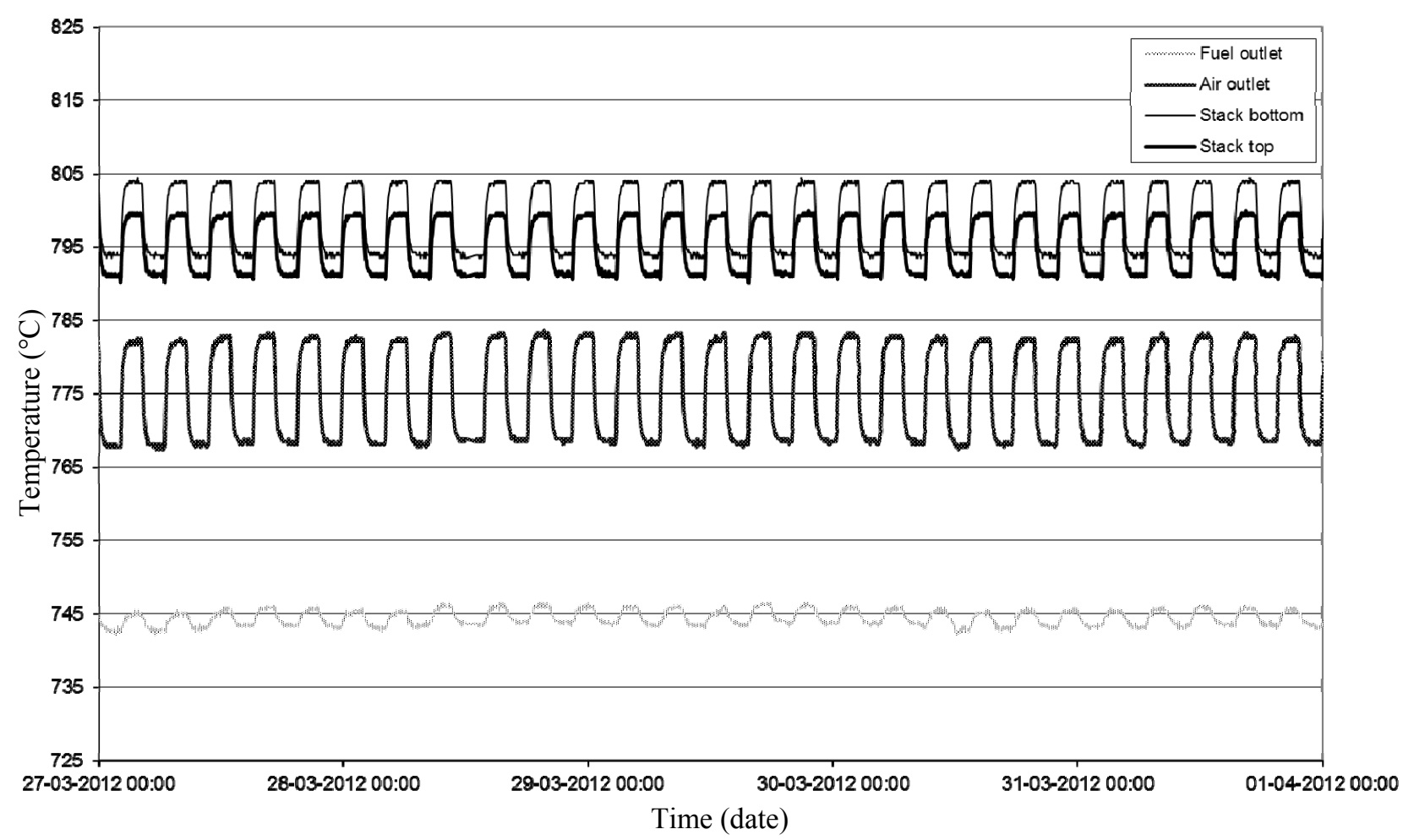

Fig. 10 Temperature variation during cycles between $300 \mathrm{~mA} \cdot \mathrm{cm}^{-2}$ and $-300 \mathrm{~mA} \cdot \mathrm{cm}^{-2}$ at high temperature operation. The low temperature intervals represent electrolysis operation. 


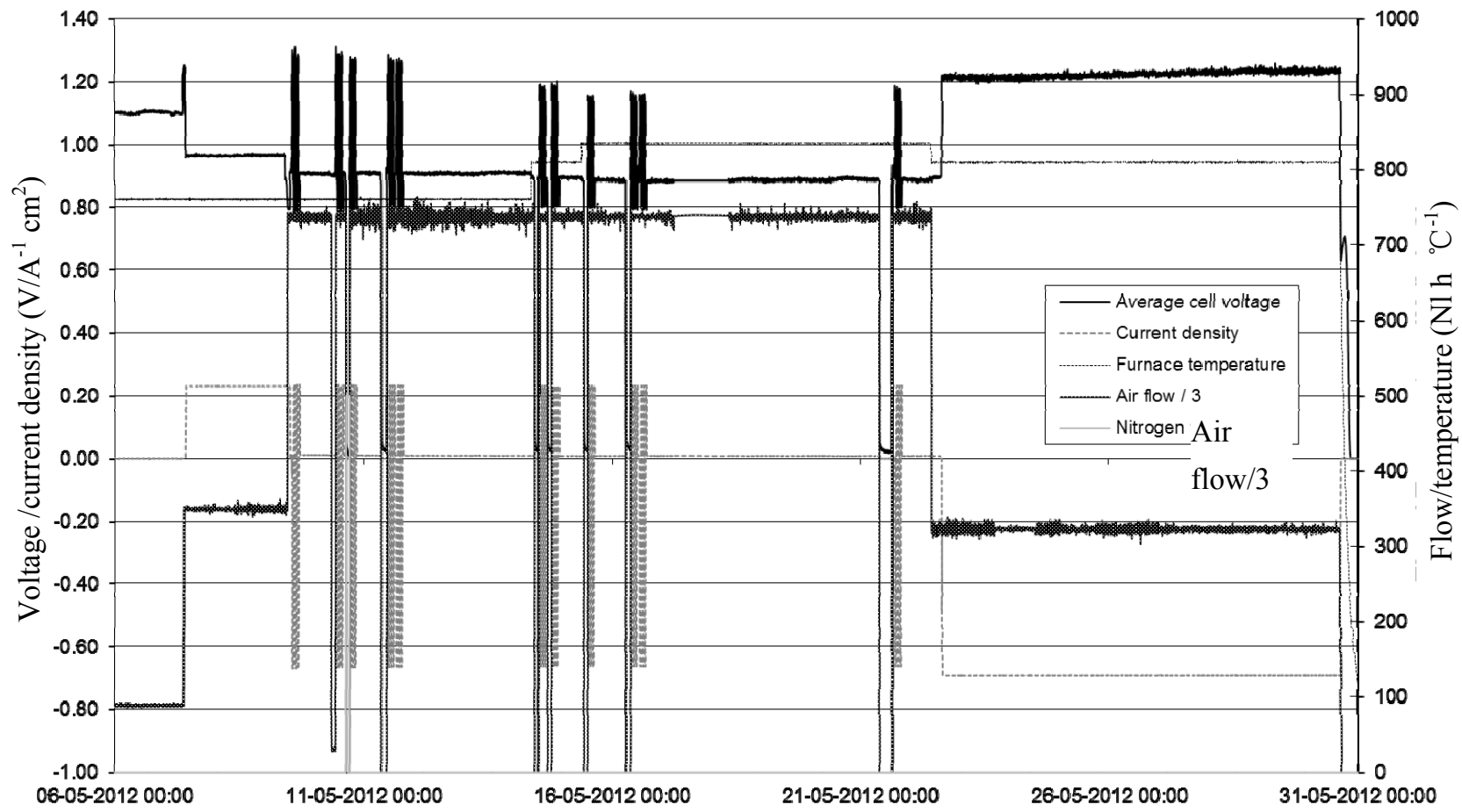

Time (date)

Fig. 11 Overview of test sequence; including the average cell voltage, current density, air and nitrogen flow to the oxygen side of the cells and the furnace temperature.

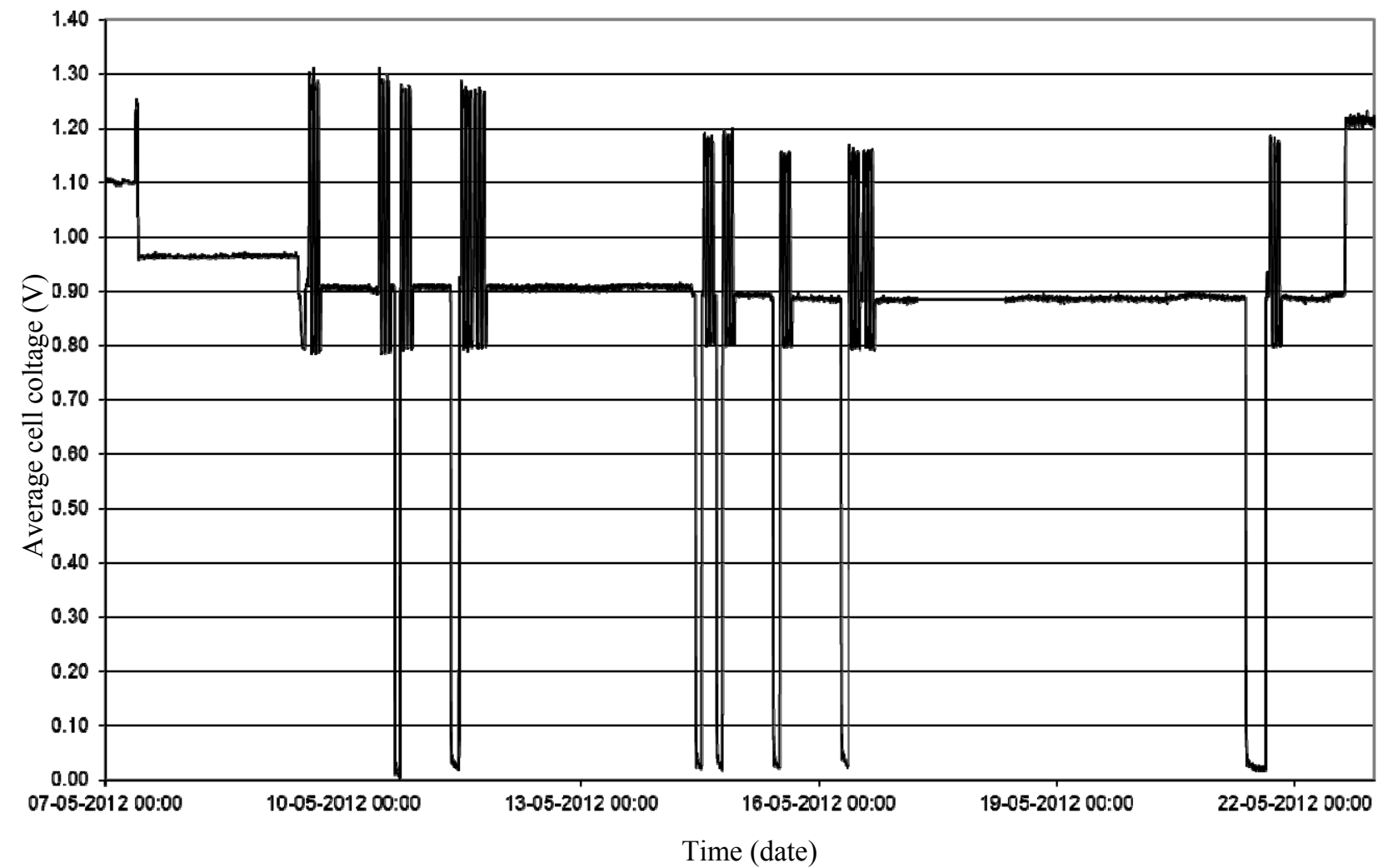

Fig. 12 Average cell voltage during test of air supply loss effects. 


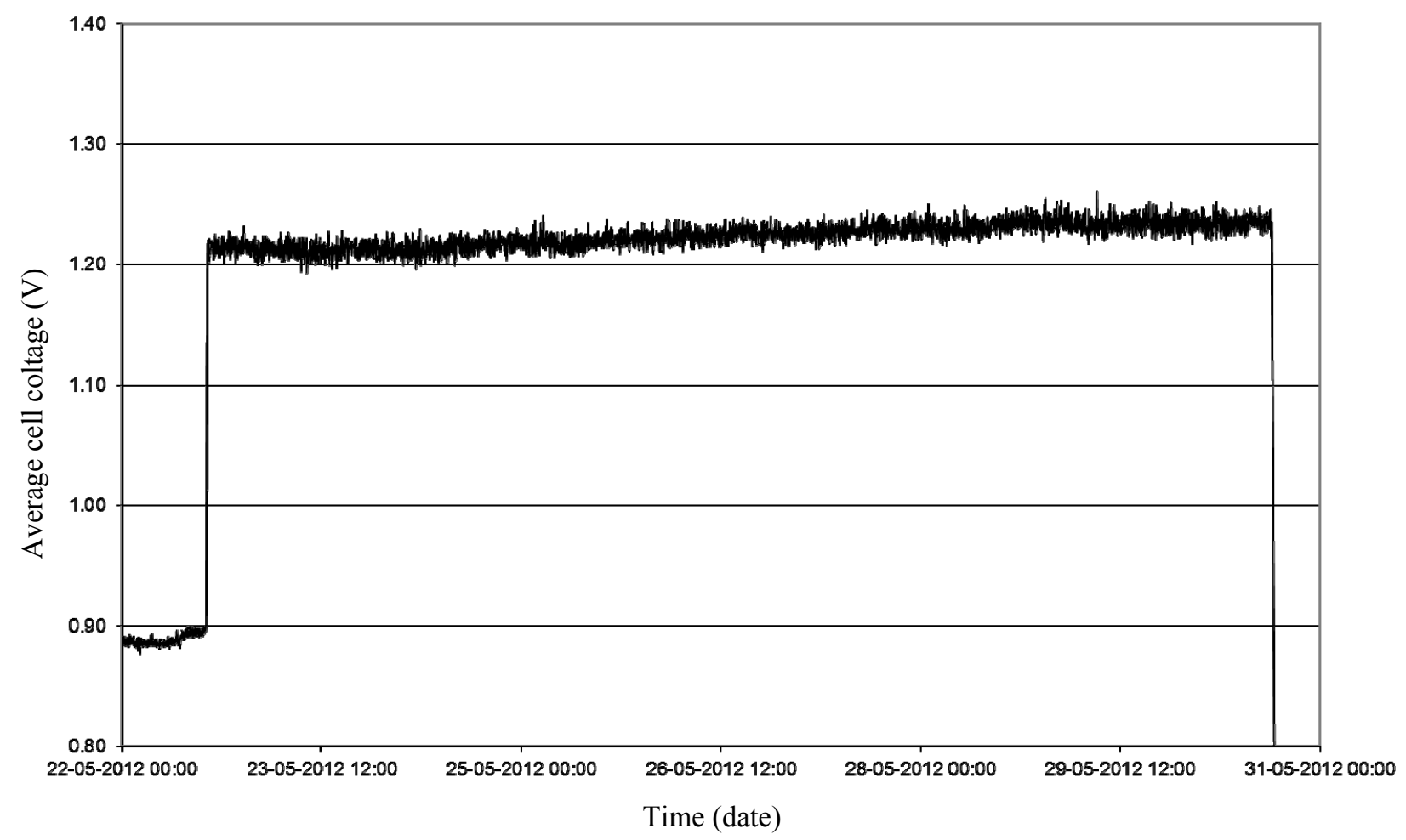

Fig. 13 Average cell voltage during degradation test at $-690 \mathrm{~mA} \cdot \mathrm{cm}^{-2}$.

A SOFC operation showed any contact loss. Thus, it can be concluded that the stacks could withstand OCV with no air flow and $835^{\circ} \mathrm{C}$ surroundings without a measurable contact loss. The previous test parts are to be considered less harsh. The following SOEC degradation test shoved a degradation rate of $151 \mathrm{~m}$ $\Omega \cdot \mathrm{cm}^{2} \cdot \mathrm{kh}^{-1}$, which is higher than normal SOEC degradation rate. This high degradation is not seen immediately after the end of the robustness test, thus, it is probably not a sign of contact loss which usually show rather rapidly. However, the test may have caused phase changed without an actual contact loss occurring which may give rise to a higher degradation rate.

\subsection{Stack Behaviour at Fuel Loss}

When the $\mathrm{CO}_{2}$ supply fails during $\mathrm{CO}_{2}$ electrolysis, the conversion of $\mathrm{CO}_{2}$ into $\mathrm{CO}\left(\mathrm{CO}_{2} \rightarrow \mathrm{CO}+1 / 2 \mathrm{O}_{2}\right)$ is expected to stop and the related electrolysis current will drop. This fits with the starvation experiment presented in Fig. 14, which shows a marked reduction in current, from $345 \mathrm{~mA} \cdot \mathrm{cm}^{-2}$ in $\mathrm{CO}_{2}$ electrolysis operation, to 24
$\mathrm{mA} \cdot \mathrm{cm}^{-2}$ after the interruption of the $\mathrm{CO}_{2}$ flow. The transfer from $\mathrm{CO}_{2}$ electrolysis operation to a stable mode without $\mathrm{CO}_{2}$ fuel takes approximately $4 \mathrm{~min}$, including 2 min for ramping down the $\mathrm{CO}_{2}$ flow. As soon as the $\mathrm{CO}_{2}$ flow starts to decrease, the stack bias increases. The upper limit (here $14.4 \mathrm{~V}$ ) is reached fast, whereupon the current decreases. When the $\mathrm{CO}_{2}$ flow is practically gone, the current levels out and $2 \mathrm{~min}$ later, it stabilized at $7 \%$ of the original value. The observed trends can to a large extent be explained based on the Nernst equation for the $\mathrm{CO}_{2}$ electrolysis reaction 1 :

$$
E_{\text {cell }}=I_{\text {cell }} R_{\text {cell }}+E_{0}+\frac{R T}{2 F} \ln \left(\frac{p_{C O} \sqrt{p_{O_{2}}}}{p_{C O_{2}}}\right)
$$

Here, $E_{\text {cell }}, I_{\text {cell }}$ and $R_{\text {cell }}$ are the voltage, current and resistivity of a cell, and $p_{\mathrm{CO}_{2}}, p_{\mathrm{CO}}$, and $p_{\mathrm{O}_{2}}$ are the partial pressures (in bar) of $\mathrm{CO}_{2}, \mathrm{CO}$ and $\mathrm{O}_{2}$ on the relevant sides, respectively. In current-limited $\mathrm{CO}_{2}$ electrolysis, the applied voltage is regulated to maintain the requested current. When the $\mathrm{CO}_{2}$ pressure drops, a higher bias is applied to compensate for the 


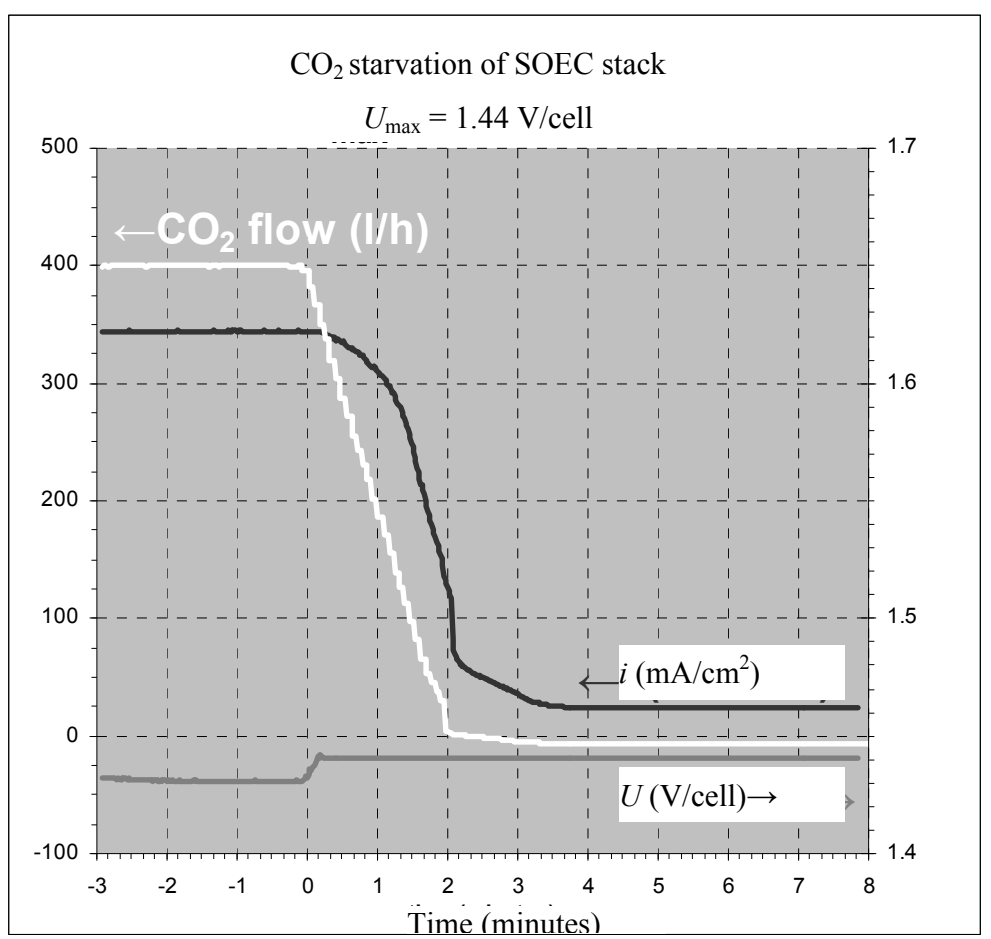

Fig. 14 Current and voltage response to starvation during $\mathrm{CO}_{2}$ electrolysis. The $\mathrm{CO}_{2}$ flow is ramped down and becomes nearly absent after 2 minutes. The upper maximum for the voltage supplied from the power supply corresponds to 1.44 $\mathrm{V} \cdot$ cell $^{-1}$.

increase in the Nernst potential. However, when the voltage-limit is reached, the electrolysis current can no longer be maintained, leading to a decrease in the current. As this effect occurs, it can be expected that no damage occurs to the cells.

When the $\mathrm{CO}_{2}$ flow is closed (after $2 \mathrm{~min}$ ), the current reduction stagnates before a stable current is reached. The stagnation period probably reflects gradual conversion of $\mathrm{CO}_{2}$ left in the fuel electrode channels. The stable current observed 2 min later is attributed to small internal leakages in the stack.

\section{Conclusion}

SOEC stack robustness towards fluctuating operation as well as towards possible operation failures which may occur for SOEC systems have been tested:

It has been shown that the stacks are highly robust towards temporary loss of fuel;

The cells are not prone to contact loss due to temporary loss of air for time spans which would usually give room for attending to the occurring problem. An increased degradation rate may, however, be a result;

It has also been shown that there may be a temperature window between 760 and $790{ }^{\circ} \mathrm{C}$ with a low degradation rate. This will need further verification;

The Topsoe Delta Stacks have shown to be very robust towards cycling between electrolysis and fuel cell operation modes and, thus, towards changing temperature distributions. A higher electrolysis load than fuel cell load is recommendable for anode supported cells in order to obtain a more even temperature between the two modes.

Future studies will further map out the possible operating windows for operation with low degradation and little probability for sudden failures.

\section{Acknowledgement}

The Danish technology funding scheme ForskEl is acknowledged for its financial support. 


\section{References}

[1] Dutta, S. 1990. "Technology Assessment of Advanced Electrolytic Hydrogen Producion." Int. J. Hydrogen Energy 15: 379-86.

[2] Energinet.dk. 2010. "Energi 2050 Vindspor." Accessed January 28, 2011. www.energinet.dk.

[3] Stoots, C. M., O'Brian, J. E., Condie, K. G., and Hartvigsen, J. J. 2010. "High-Temperature Electrolysis for Large-Scale Hydrogen Production from Neclear Energy-Experimental Investigations.” Int. J. of Hydrogen Energy 35: 4861-70.

[4] Cai, Q., Luna-Ortiz, E., Adjiman, C. S., and Brandon, N. P. 2010. "The Effects of Operating Conditions on the Performance of a Solid Oxide Steam Electrolyser: A Model-Based Study." Fuel Cells 10: 1114-28.

[5] Udagawa, J., Aguiar, P., and Brandon, N. P. 2008. "Hydrogen Production Steam Electrolysis: Control Strategies for a Cathode-Supported Intermediate Temperature Solid Oxide Electrolysis Cell." J. of Power Science 180: 354-64.

[6] Xie, L., Carvalho, P. M. S., Ferreira, L. A. F. M., Liu, J., Krogh, B. H., Popli, N., and Ilic, M. D. 2011. "Integration in Power Systems: Operational Challenges and Possible Solutions." Proceeding of the IEEE 99: 214-32.

[7] Virkar, A. V. 2010. "Mechanism of Oxygen Electrode Delamination in Solid Oxide Electrolyzer Cells.” Int. J. of Hydrogen Energy 35 (18): 9527-43.

[8] Sohal, M. S., O’Brien, J. E., Stoots, C. M., Sharma, V. I., Yildiz, B., and Virkar, A. 2012. "Degradation Issues in Solid Oxide Cells During High Temperature Electrolysis." J. of Fuel Cell Science and Technology 9 (1): 10-1.

[9] Laguna-Becero, M. A., Campana, R., Larrea, A., Kilner, J.
A., and Orera, V. M. 2011. "Electrolyte Degradation in Anode Supported Microturbular Stabilized Zirconia-Based Solid Oxide Steam Electrolysis Cells at High Voltage Of Operation." J. of Power Sources 196: 8942-7.

[10] Mawdsley, J. R., Carter, J. D., Kropf, A. J., Yildiz, B., and Maroni, V. A. 2009. "Post-Test Evaluation of Oxygen Electrods from Solid Electrolysis Stacks." Int. J. of Hydrogen Energy 34: 4198-207.

[11] Pérez-Coll, D., Núnez, P., and Frade, J. R. 2011. Advances in Ceramics-Synthesis and Characterizatio., In Processing and Specific Applications, InTech, Rijeka Croatia, 337-62.

[12] Lein, H. L., Wiik, K., and Grande, T. 2006. "Thermal and Chemical Expansion of Mixed Conducting La0.5Sr0.5Fe1-xCoxO3- Materials." Solid State Ionics 177: 1587-90.

[13] Touzelin, B. 1981. "Study of the Iron-Cobalt-Oxygen System at $900{ }^{\circ} \mathrm{C}$ by Thermogravimetry and High-Temperature X-ray Diffraction.” J. Less-Common Met. 77 (1): 11-27.

[14] Eguchi, K., Hatagishi, T., and Arai, H. 1996. "Power Generation and Steam Electrolysis Characteristics of an Electrochemical Cell with a Zirconia- or Ceria-Based Electrolyte." Solid State Ionics 86-88: 1245-9.

[15] Marina, O. A., Pederson, L. R., Williams, M. C., Coffey, G. W., Meinhardt, K. D., Nguyen, C. D., and Thomsen, E. C. 2007. "Electrode Performance in Reversible Solid Oxide Fuel Cells." J. of Electrochemical Society 154: B452-B459.

[16] Kim-Lohsoontorn, P., and Bae, J. 2011. "A Raman Spectroscopic Study of the Carbon Deposition Mechanism on $\mathrm{Ni} / \mathrm{CGO}$ Electrodes during $\mathrm{CO} / \mathrm{CO}_{2}$ Electrolysis." J. of Power Sources 196: 7161-8. 